\title{
Changes in lipid profile during growth and senescence of Catharanthus roseus leaf
}

\author{
Sanjay Mishra ${ }^{1 *}$, Abhishek Tyagi ${ }^{1}$, I.V. Singh ${ }^{1}$, and R.S. Sangwan ${ }^{2}$ \\ ${ }^{1}$ Department of Biotechnology, College of Engineering and Technology, IFTM Campus, Lodhipur Rajput, Moradabad 244 001, U.P., \\ India. ${ }^{2}$ Division of Plant Physiology and Biochemistry, Central Institute of Medicinal \& Aromatic Plants, P.O. CIMAP, Near Kukrail \\ Picnic Spot, Lucknow 226 015, U.P., India. *Corresponding author: sanjay_mishra23@rediffmail.com or \\ sanjay_mishra23@hotmail.com
}

Received: 14 October 2006; Returned for revision: 27 November 2006; Accepted: 03 February 2007

Various lipid classes and compounds were monitored during the period of leaf emergence to leaf drop of Catharanthus roseus. The expansion to early maturation phase was accompanied by cellular build-up of all major lipid classes, whilst aging and senescence were characterized by their substantial decline, except for the neutral lipids; the leaf monogalactosyl diglyceride/digalactosyl diglyceride ratio decreased from 4.3 (complete maturity) to 2.1 (abscised stage). The early maturation stage was the earliest stage when appreciable amounts of free sterols and fatty acids could be observed. Sterol/phospholipids ratios increased by 68 -fold in the abscised leaf as compared to that at full maturity. The unsaturated/saturated fatty acid ratio was far lower in the senescent leaf as compared to that of the fully expanded leaf. The spatial alterations in lipid profiles may be suggestive of concomitant changes in membrane ultrastructure and functions, putatively leading to perturbation of indole alkaloid sequestration capability of the tissues of a species of pharmaceutical significance.

Key words: Catharanthus roseus, glycolipids, leaf development, phospholipids, senescence, sterol

Alterações no perfil de lipídeos durante o crescimento e a senescência de folhas de Catharanthus roseus: Rastrearamse alterações na composição de vários compostos e classes de lipídeos em folhas de Catharanthus roseus, desde a emergência até a abscisão. Da expansão ao início da maturação da folha, houve incrementos nas concentrações de todas as principais classes de lipídeos, observando-se tendência oposta na senescência, à exceção de lipídeos neutros; a razão monogalactosil diglicerídeo/digalactosil diglicerídeo decresceu de 4.3 (maturidade completa) para 2.1 (abscisão). Quantidades apreciáveis de esteróis e ácidos graxos começaram a ser observadas apenas no início maturação foliar. A razão esteróis/fosofolipídeos aumentou 68 vezes na fase de abscisão em relação à folha em sua completa maturidade. A razão ácidos graxos insaturados/ácidos graxos saturados foi muito menor na folha senescente que na folha jovem completamente expandida. As alterações espaciais no perfil de lipídeos podem ser uma sugestão de alterações concomitantes na função e ultra-estrutura da membrana, acarretando, putativamente, perturbações na capacidade de seqüestro de alcalóides dos tecidos de uma espécie importante, de um ponto de vista farmacêutico.

Palavras-chave: Catharanthus roseus, desenvolvimento foliar, esteróis, fosfolipídeos, glicolipídeos, senescência

\section{INTRODUCTION}

Catharanthus roseus (L.) G. Don, known as the common or Madagascar periwinkle, is a perennial and evergreen herb of the dogbane family (Apocynaceae) that was originally native to the island of Madagascar. It has been widely cultivated for hundreds of years and can now be found growing wild in most warm regions of the world, including the Southern U.S. The plants grow one or two feet high, have glossy, dark green leaves (1-2 inches long) and flowers all summer long. Vincristine (Oncovin) and vinblastine (Navelbine), the main indole alkaloids produced by this plant, are medicinally important, having long been used as anticancerous agents (Blasko and Cordell, 1990; Verpoorte et al., 1991). In fact, these secondary metabolites are produced at extremely low levels within the plants and remain resistant to chemical 
attack due to their complex structures (Verpoorte et al., 1999; Hughes and Shanks, 2002). During the last decade, a lot of effort has been made with the view to exploring primary to secondary metabolite networks for terpenoid indole alkaloid biosynthesis in C. roseus (Canel et al., 1998; Sangwan et al., 1998; van der Fits and Memelink, 2000; Ayora-Talavera et al., 2002; Hughes et al., 2002, 2004; Whitmer et al., 2002a,b). However, lipid metabolism together with qualitative and quantitative production and sequestration of medicinally and biotechnologically valuable phytochemicals in C. roseus is still a fast developing and promising area in which to work.

Lipids are basically structural and functional molecules of plant cells and tissues. They are known to affect certain membrane properties like permeability, fluidity and transport. In particular, lipids are sensitive to any change in physiological state as well as biotic and abiotic environments (Brown et al., 1987; Droillard et al., 1989; Duxbury et al., 1991; Paliyath and Droillard, 1992). The length and degree of unsaturation of fatty acids, the nature of sterols and the sterol/phospholipids ratio, collectively affect the fluidity of the membrane bilayer (Duxbury et al., 1991). Metabolically, certain alterations in lipid content and composition may be seen in relation to development of intracellular membranous compartmentation and the availability of intracellular (non-plasmic and periplasmic) spaces. Since vacuoles are intracellular spaces which function as accumulation sites for many alkaloids (Matile, 1987; Lichtenthaler, 1999; Morgan and Shanks, 2000; Estevez et al., 2001; Mahmud and Croteau, 2001; Silvestrini et al., 2002), vacuolar membranes might play a pivotal role in compartmentalized acquisition, sequestration and retention of certain secondary metabolites, including alkaloids. Our earlier studies have revealed remarkable changes in secondary phytochemical accumulation in the Duboisia myoporoides leaf accompanying its various developmental phases (Mishra and Sangwan, 1996).

To explain the phasic pattern, it has been proposed that production and accumulation of secondary phytochemicals require a defined cellular organization and follow a preset developmental programme. This may be correlated with the building-up and maintenance of a cellular endoplasmic system, homeostasis, etc., besides other metabolic factors. Thus, as a part of promising investigations along these lines and their biotechnological applications, it is meaningful to examine the temporal profile of various lipid classes and components with the aim of providing new insights in indole alkaloid accumulation during defined physiological phases of the C. roseus leaf.

\section{MATERIAL AND METHODS}

Plant materials: Leaf samples were harvested from plants of $C$. roseus growing in the experimental farm of the CIMAP, at Lucknow $\left(26.5^{\circ} \mathrm{N}, 80.5^{\circ} \mathrm{E}, 120 \mathrm{~m}\right.$ a.s.1., subtropical zone), India. Individual leaf buds were tagged on the day of appearance and sampling began $7 \mathrm{~d}$ later. Additional samples were taken at $7 \mathrm{~d}$ intervals until leaf abscission occurred about $77 \mathrm{~d}$ after tagging. The experiments were performed from July to October, a time period characterized by a day length of $12 \pm 1.5 \mathrm{~h}$ and average day and night temperature of approximately 30 and $20^{\circ} \mathrm{C}$, respectively.

Lipid extraction and analysis: Total lipids were extracted with $\mathrm{CHCl}_{3}-\mathrm{MeOH} 2: 1(\mathrm{v} / \mathrm{v})$ and purified with the use of 0.2 volumes of aqueous $0.9 \%$ (w/v) $\mathrm{NaCl}$ (Matile, 1987). The purified lipid fraction was evaporated to dryness and the residue weighed. Total fatty acids were determined as previously described (Mishra and Sanwal, 1994).

Lipids were fractionated into neutral, glyco- and phospholipids by S-gel CC eluting in sequence with $\mathrm{CHCl}_{3}$, acetone, and $\mathrm{MeOH}$ (Rouser et al., 1976). Purity of each fraction was checked by bidimensional thin-layer chromatography (TLC) using as solvent systems $\mathrm{CHCl}_{3}$ $\mathrm{MeOH}-28 \% \mathrm{NH}_{4} \mathrm{OH}$ 65:35:5 (v/v) followed by $\mathrm{CHCl}_{3}$ acetone-MeOH-AcOH- $\mathrm{H}_{2} \mathrm{O}$ 5:2:1:1:0.5 (v/v). The chloroform eluate contained neutral lipids, namely pigments, sterols and nonconjugated fatty acids. The acetone eluate contained glycolipids, whereas the methanol eluate represented mostly phospholipids with traces of glycolipids. Quantitation of each lipid class was performed on the basis of their dry weight determination. Free sterols and nonconjugated fatty acids in the neutral lipid fraction were estimated according to Stadtman (1957) and Lowry and Tinsley (1976), respectively. The glycolipid fraction was freed of trace impurities through TLC on SI-gel G plates employing the solvent system $\mathrm{CHCl}_{3}$-acetone-MeOH-AcOH-H 0 5:2:1:1:0.5 (v/v). Identification of individual glycolipids was carried out by running authentic reference standards simultaneously and also by staining with á-naphthol reagent (Siakotes 
and Rouser, 1965) and water spray (used to facilitate observations of translucent areas on the TLC plates) (Gardner, 1968) was employed for identification and analytical purposes. The separated glycolipids were estimated on the basis of sugar released after hydrolysis (Roughan and Batt, 1968).

Fatty acid composition: For determination of fatty acid composition, methyl esters were prepared (Jham et al., 1982). Fatty acid methyl esters were separated and detected using an AIMIL-Nucan gas chromatograph fitted with a stainless steel column ( $1.8 \mathrm{~m} \times 2 \mathrm{~mm}$, i.d.) of $20 \%$ di-ethylene glycol succinate on Chromosorb W (100120 mesh). The operating conditions were as follows: oven temperature, $190^{\circ} \mathrm{C}$; flame ionization detector and injector temperature, $220^{\circ} \mathrm{C}$; flow rate of $\mathrm{H}_{2}$ and $\mathrm{N}_{2}, 30 \mathrm{~mL}$ $\mathrm{min}^{-1}$. The identification of fatty acid methyl esters was performed by employing authentic reference standards. The peak area was calculated by measuring the height multiplied by the width of the peak at half peak height. The values for each fatty acid are given as percent by weight of total fatty acids.

\section{RESULTS AND DISCUSSION}

Specific changes in leaf development beginning from $7 \mathrm{~d}$ after leaf primordial initiation up to abscission include leaf expansion until $28 \mathrm{~d}$, maturation and aging from 35 to $56 \mathrm{~d}$, and senescence initiation by $63 \mathrm{~d}$. Fresh weight and dry weight of leaves increased rapidly during leaf development, attaining maximum values by $35 \mathrm{~d}$ after initiation of bud emergence (Figure 1). Subsequently, leaf weights declined until the end of growth at $77 \mathrm{~d}$. Moisture content of leaf tissue fluctuated from 62 to $88 \%$ (Table 1). One of the characteristic alterations that occur within cells of senescing leaves is the deterioration of membranes. Alterations in cell membrane composition and integrity reflect changes in membrane permeability. Therefore, an understanding of changes in lipid metabolism and lipid content of senescing tissue is fundamental to an understanding of senescence. These complex regulatory cellular and metabolic interactions may influence production, transport and accumulation of indole alkaloids in the developing $C$. roseus leaf. In the present investigation, changes in lipid content and composition of the Catharanthus leaf from initiation of leaf emergence to leaf drop have been examined. The changes in moisture percentage appear far less prominent

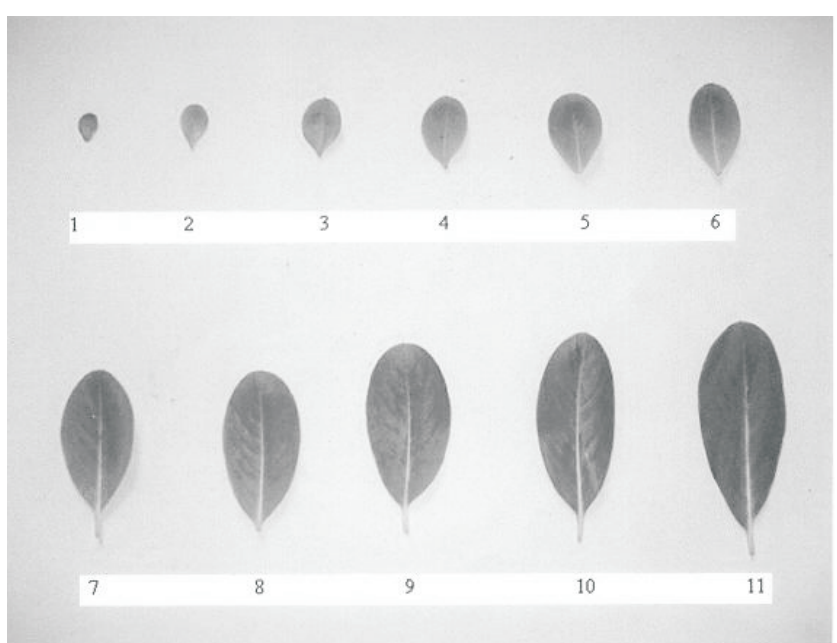

Figure 1. Different developmental stages of leaves of Catharanthus roseus. Stages of the plant leaves were designated as: $1(7 \mathrm{~d}), 2(14 \mathrm{~d})$ to $4(28 \mathrm{~d})=$ expansion; 5 (35 d) to $8(56 \mathrm{~d})=$ maturing and aging; $9(63 \mathrm{~d})$ to $11(77 \mathrm{~d})=$ senescence and abscission.

Table 1. Leaf changes associated with developments of C. roseus.

\begin{tabular}{cccc}
\hline $\begin{array}{c}\text { Leaf age } \\
(\text { days })\end{array}$ & $\begin{array}{c}\text { Fresh weight } \\
\left(\text { mg leaf }^{-1}\right)\end{array}$ & $\begin{array}{c}\text { Dry weight } \\
\left(\text { mg leaf }^{-1}\right)\end{array}$ & $\begin{array}{c}\text { Leaf moisture } \\
\text { content }(\%)\end{array}$ \\
\hline 7 & 10.5 & 3.4 & 86 \\
14 & 21.8 & 9.9 & 81 \\
21 & 75.6 & 30.4 & 76 \\
28 & 222.8 & 69.6 & 69 \\
35 & 575.8 & 158.9 & 62 \\
42 & 425.8 & 112.6 & 70 \\
49 & 310.4 & 74.6 & 75 \\
56 & 290.5 & 64.3 & 77 \\
63 & 250.3 & 51.4 & 79 \\
70 & 210.5 & 39.6 & 83 \\
77 & 176.7 & 31.3 & 88 \\
\hline
\end{tabular}

than those in fresh and dry weights (Table 1). The profiles up to the 35-42 d period represent consistent cellular build-up leading to net biomass accumulation. The subsequent period is almost deteriorative in gross metabolic terms. This is substantiated by the observed parallel enhancement in leaf expansion and chlorophyll content (Mishra and Sangwan, 1996). The 35-56 d phase is a characteristic period of leaf maturation and aging phenomenon. The senescence phase (day 56 onwards) accompanies a rapid decrease in chlorophyll level. In 
fact, breakdown of chlorophyll and a concomitant enhancement in carotenoids are well-established components of senescence (Thomas and Stoddart, 1980).

The total lipid content, expressed as $\mu \mathrm{g}$ per leaf (Table 2), increased during expansion to attain a maximal level of $373 \mu \mathrm{g}$ per leaf at full maturity. However, no marked changes occurred during aging whereas progress of senescence was accompanied by a substantial decline in lipid content. The amount of individual lipid classes per leaf varied grossly in a similar fashion as total lipids except that during aging and senescence initiation the glyco- and phospholipids declined to a far greater extent than the neutral lipids. On the $7^{\text {th }}$ day after proliferation, amongst the lipid classes, neutral lipids were observed to be the most abundant. No consistent pattern of distribution of neutral, glyco- and phospholipids was found up to $28 \mathrm{~d}$ of leaf ontogeny. The average percentages were recorded to be $47,22.7$ and $30.3 \%$, respectively. The period of maturation, aging and senescence accompanied a slow but consistent trend of decline in glyco- and phospholipids. Enhancement in the proportion of neutral lipids during this phase was clearly evident.

Overall, the leaf drop stage witnessed a significant increase in neutral lipids and remarkable decline in glycoand phospholipids, as compared to their level in the fully expanded leaf. Specifically, both glycolipids and phospholipids dropped to a greater extent during maturation up to the onset of senescence. It was also noteworthy that the monogalactosyl diglyceride (MGDG)/digalactosyl diglyceride (DGDG) ratio of the Catharanthus leaf (Table 3) decreased from 4.3 (at complete maturity) to 2.1 (abscised stage) which may be suggestive of substantial changes in ultrastructure, fluidity and permeability of the membrane. An earlier study revealed a greater decrease in MGDG/DGDG ratio in salt-stressed jojoba leaves (Ben-Rais et al., 1993). A report on Duboisia in reference to aging and senescence also entails a significant decrease in MGDG/DGDG ratio (Mishra et al., 1998). It was speculated that the change in their proportion is likely to be correlated with a change in physical properties of organellar membranes (Ben-Rais et al., 1993; Mishra et al., 1998). Besides, many studies have revealed that membranes in mature tissues are in liquid crystalline state, while in senescent tissue the membranes or a portion thereof, are in the crystalline gel
Table 2. Total and by class distributed lipid contents at different developmental stages of C. roseus. Values are the mean \pm SD of three sets of experiments with triplicates in each set and expressed as $\mu \mathrm{g} \mathrm{leaf}^{-1}$.

\begin{tabular}{ccccc}
\hline $\begin{array}{c}\text { Leaf age } \\
\text { (days) }\end{array}$ & $\begin{array}{c}\text { Total } \\
\text { lipids }\end{array}$ & $\begin{array}{c}\text { Neutral } \\
\text { lipids }\end{array}$ & $\begin{array}{c}\text { Glyco- } \\
\text { lipids }\end{array}$ & $\begin{array}{c}\text { Phospho- } \\
\text { lipids }\end{array}$ \\
\hline 7 & $4.9 \pm 0.2$ & $2.7 \pm 0.2$ & $1.5 \pm 0.2$ & $0.8 \pm 0.02$ \\
14 & $15.5 \pm 0.9$ & $9.5 \pm 0.8$ & $5.1 \pm 0.4$ & $0.9 \pm 0.06$ \\
21 & $59.6 \pm 1.7$ & $35.3 \pm 1.8$ & $15.2 \pm 1.0$ & $9.1 \pm 0.3$ \\
28 & $165.4 \pm 3.2$ & $77.9 \pm 2.3$ & $37.5 \pm 1.4$ & $50.0 \pm 0.4$ \\
35 & $351.5 \pm 5.3$ & $263.7 \pm 3.1$ & $66.9 \pm 2.7$ & $40.0 \pm 1.1$ \\
42 & $372.5 \pm 2.9$ & $268.9 \pm 3.8$ & $90.4 \pm 3.0$ & $20.0 \pm 0.6$ \\
49 & $370.6 \pm 5.1$ & $275.9 \pm 3.2$ & $84.1 \pm 2.3$ & $12.5 \pm 1.1$ \\
56 & $365.0 \pm 2.8$ & $270.4 \pm 3.1$ & $82.4 \pm 1.7$ & $12.2 \pm 0.7$ \\
63 & $356.9 \pm 2.7$ & $265.3 \pm 3.7$ & $80.9 \pm 1.4$ & $10.7 \pm 0.3$ \\
70 & $351.2 \pm 2.1$ & $262.8 \pm 2.8$ & $77.9 \pm 1.1$ & $10.5 \pm 0.2$ \\
77 & $253.8 \pm 1.5$ & $198.5 \pm 3.1$ & $47.3 \pm 0.8$ & $8.0 \pm 0.4$ \\
\hline
\end{tabular}

Table 3. Alterations in glycolipid composition with respect to development differentiation of $C$. roseus leaf. Values are the mean $\pm \mathrm{SD}$ of three sets of experiments with triplicates in each set and expressed as $\mu \mathrm{g}$ leaf ${ }^{1}$. MGDG $=$ monogalactosyl diglycerides; $\mathrm{DGDG}=$ digalactosyl diglycerides; $\mathrm{SQDG}=$ sulfoquinovosyl diglycerides.

\begin{tabular}{ccccc}
\hline $\begin{array}{c}\text { Leaf age } \\
\text { (days) }\end{array}$ & MGDG & DGDG & SQDG & $\begin{array}{c}\text { MGDG/ } \\
\text { DGDG }\end{array}$ \\
\hline 7 & $0.6 \pm 0.02$ & $0.5 \pm 0.02$ & $0.4 \pm 0.02$ & 1.1 \\
14 & $3.1 \pm 0.19$ & $1.5 \pm 0.03$ & $0.5 \pm 0.01$ & 2.1 \\
21 & $10.8 \pm 1.0$ & $3.7 \pm 0.21$ & $0.7 \pm 0.02$ & 2.9 \\
28 & $27.9 \pm 1.1$ & $7.8 \pm 0.24$ & $1.9 \pm 0.05$ & 3.7 \\
35 & $49.5 \pm 1.4$ & $12.4 \pm 1.2$ & $4.8 \pm 0.04$ & 4.1 \\
42 & $65.6 \pm 1.6$ & $15.3 \pm 0.9$ & $9.5 \pm 0.6$ & 4.3 \\
49 & $62.6 \pm 1.5$ & $13.3 \pm 0.8$ & $8.2 \pm 0.5$ & 4.7 \\
56 & $61.5 \pm 1.5$ & $12.8 \pm 1.1$ & $8.1 \pm 0.8$ & 4.9 \\
63 & $60.3 \pm 1.3$ & $13.4 \pm 0.8$ & $7.2 \pm 0.5$ & 4.6 \\
70 & $56.4 \pm 1.4$ & $14.8 \pm 0.8$ & $6.7 \pm 0.2$ & 3.8 \\
77 & $28.5 \pm 2.4$ & $13.6 \pm 0.7$ & $5.2 \pm 0.2$ & 2.2 \\
\hline
\end{tabular}

phase at physiological temperatures (Lees and Thompson, 1980; Chia et al., 1981). Thus, the membrane phase alteration may be a consequence of qualitative changes in membrane lipids like glycolipids, phospholipids and MGDG/DGDG ratio. 
As far as sterols and free fatty acids (FFA) are concerned, they are present in trace amounts up to 28 days of leaf ontogeny. Only at the $35 \mathrm{~d}$ stage appreciable amounts of free sterols and FFA were observed (Table 4). During maturation, aging and senescence, FFA were found to enhance considerably. It is well known that during aging and senescence, the catabolic enzymatic activities become activated. The first step is the expression of a lipase system followed by lipoxygenase and certain cleaving enzymes (Dalgarn and Newman, 1986). The percent conjugation of fatty acids was almost total during the course of leaf expansion but at $35 \mathrm{~d}$ after leaf proliferation the pool of FFA started to build-up. The percent conjugation was noted to be $89 \%$ at maturity and about $69 \%$ in abscising leaves. Furthermore, the level of free sterols increased drastically during latter phase of aging and onset of senescence to reach $21.8 \mu \mathrm{g}$ at the leaf drop stage. The reason for sterol elevation is not clear. Probably, a lack of cellular proliferation during this phase results in non-utilization of the pool of sterols. Sterols at this phase are not structural components of membranes but, after esterification of FFA, esterified sterols (vacuolized in the form of triacyl glycerol) are an important source of energy for cells. Frequently, studies on changes in lipid content of senescing tissue have concentrated on the phospholipids and sterols. In microsomal, plasma and chloroplastic membranes, it has been reported that there is a $400 \%$ increase in the sterol/ phospholipids ratio as senescence progresses (Chia et al., 1981; Mishra et al., 1998). In the present study, a 67fold increase in the sterol/phospholipids ratio was observed for the Catharanthus leaf compared to that of the leaf at full maturity (Table 4).

With the progress of leaf expansion, the saturated fatty acids (capric, lauric, myristic, palmitic and stearic) increased while unsaturated fatty acids (oleic, linoleic and stearic) were found to decrease (Table 5). Changes in total fatty acid composition have been reported in many tissues undergoing senescence. Certain reports which have analyzed either the entire lipid extract of photosynthetic tissue or that of the chloroplast alone have shown a decline of more than $50 \%$ in the unsaturated/ saturated esterified fatty acid ratio during senescence and as a consequence of stress induced by an angiosperm parasite (Newman et al., 1973; Koiwai et al., 1981; Mishra and Sanwal, 1994). In the present study, at complete maturity, the unsaturated/saturated fatty acid ratio was 3.13. Later on, during aging and senescence, the ratio between unsaturated and saturated fatty acids continued to decrease, reaching 1.53 on the $77^{\text {th }}$ day of leaf proliferation (Table 5). Thus, the present study reveals an approximately $50 \%$ decline in the unsaturated/saturated fatty acids ratio of the total lipid fraction of senescent leaves compared to that of the mature leaf of $C$. roseus. This decline resembles that observed in organellar lipids of Nicotiana tabacum leaves (Koiwai et al., 1981).

Table 4. Changes in level of total fatty acids, free fatty acids, free sterols and sterolphospholipid ratio during the development of $C$ roseus leaf. Values are the mean \pm SD of three sets of experiments with triplicates in each set and expressed as $\mu$ gleaf $^{-1} . n d=$ not detected.

\begin{tabular}{cccccc}
\hline Leaf age (days) & Total fatty acids & Free fatty acids & Free sterols & $\begin{array}{c}\text { \% Conjugation of } \\
\text { fatty acids }\end{array}$ & $\begin{array}{c}\text { Sterols/ } \\
\text { phospholipids }\end{array}$ \\
\hline 7 & $2.2 \pm 0.1$ & $n d$ & $n d$ & 100 & $n d$ \\
14 & $8.9 \pm 0.5$ & $n d$ & $n d$ & 100 & $n d$ \\
21 & $30.5 \pm 1.6$ & $n d$ & $n d$ & 100 & $n d$ \\
28 & $71.5 \pm 1.8$ & $2.8 \pm 0.4$ & $1.0 \pm 0.02$ & 96.1 & 0.02 \\
35 & $246.4 \pm 3.4$ & $11.9 \pm 0.8$ & $0.8 \pm 0.02$ & 95.4 & 0.02 \\
42 & $233.4 \pm 3.1$ & $25.4 \pm 1.7$ & $0.6 \pm 0.01$ & 89.0 & 0.03 \\
49 & $228.3 \pm 2.9$ & $34.8 \pm 1.8$ & $0.5 \pm 0.01$ & 84.6 & 0.04 \\
56 & $215.6 \pm 2.1$ & $35.9 \pm 1.9$ & $23.5 \pm 1.4$ & 85.0 & 1.92 \\
63 & $212.4 \pm 1.8$ & $36.8 \pm 1.8$ & $24.2 \pm 1.3$ & 83.3 & 2.26 \\
70 & $205.1 \pm 1.4$ & $41.4 \pm 1.7$ & $26.9 \pm 1.1$ & 80.0 & 2.56 \\
77 & $135.1 \pm 1.1$ & $41.6 \pm 1.6$ & $21.8 \pm 1.1$ & 68.8 & 2.72 \\
\hline
\end{tabular}




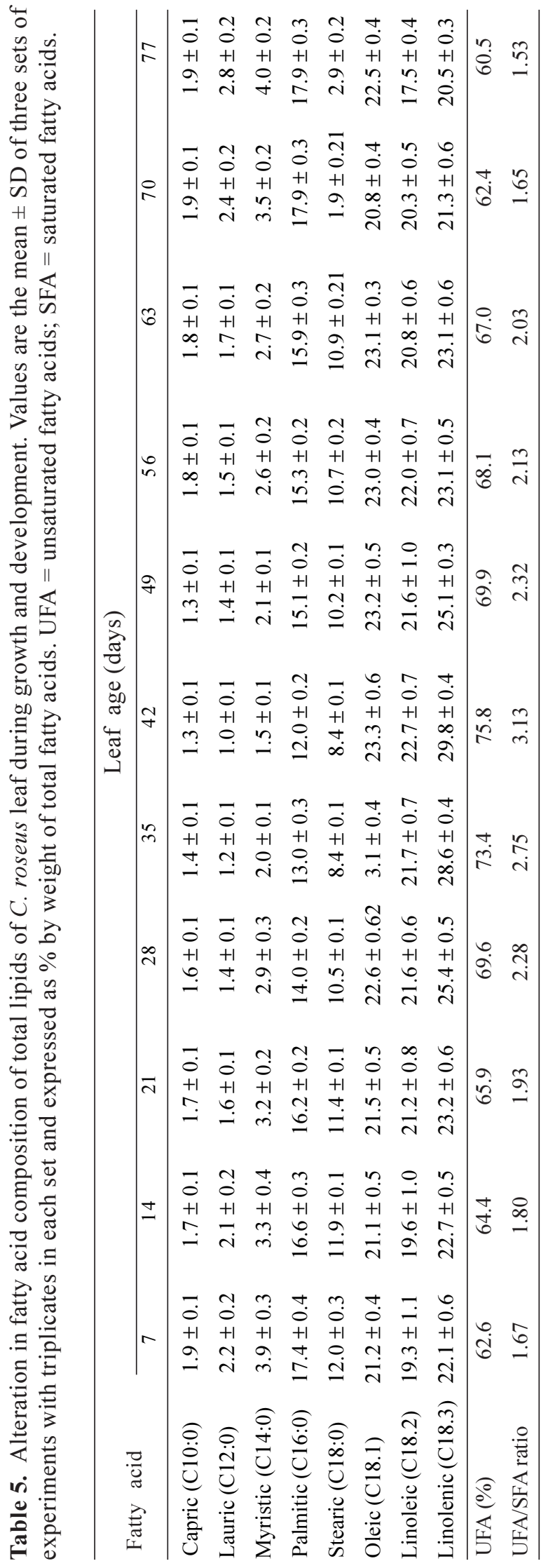

Such spatial alterations in the lipid profile have been reported to enhance membrane permeability (Suttle and Kende, 1978, 1980). The increase in permeability may be, at least partially, due to the occurrence of the crystalline gel phase in the membrane, since both an alteration in permeability and the appearance of the gel phase occur together. These changes in membranes and the resultant alterations in their functions may also be viewed in terms of accumulation/retention of secondary phytochemicals.

These findings may, at least partially, be correlated to changes in alkaloid levels during senescence in C. roseus leaf. Studies are currently underway to determine the spatial mechanism responsible for the sequestration and/or retention of indole alkaloids in leaf tissue. Furthermore, taken together, the current characterization of the lipid profile and studies on gene to metabolic networks for terpenoid indole alkaloid biosynthesis (Rischer et al., 2006) may be meaningful for biote-chnological research aimed at studying conformational changes in the vacuolar membrane in consequence of growth and senescence and their impact on storage of indole alkaloids. Work along these lines is also in progress.

Acknowledgements: The present work was supported by a joint venture of the laboratory facility at CIMAP, Lucknow, U.P., India and CET, Moradabad, U.P., India. An institutional research promotion grant to the department of Biotechnology, College of Engineering \& Technology, Moradabad, U.P., India is also acknowledged. The authors are grateful to Prof. R.M. Dubey (Managing Director, CET, IFTM, Moradabad, U.P., India) and Prof. A. Srivastava (Director, CET, Moradabad, U.P., India) for providing the necessary facilities and encouragement. Dr. S.K. Maheshwari is thanked for critical reading of the manuscript, helpful advice and valuable discussion.

\section{REFERENCES}

Ayora-Talavera T, Chappell J, Lozoya-Gloria E, Loyola-Vargas VM (2002) Overexpression in Catharanthus roseus hair roots of a truncated hamster 3-hydroxy-3-methylglutaryl-CoA reductase gene. Appl. Biochem. Biotechnol. 97:135-145.

Ben-Rais L, Alpha MJ, Bhal J (1993) Lipid and protein contents of jojoba leaves in relation to salt adaptation. Plant Physiol. 31:547-557.

Blasko G, Cordell GA (1990) Indole alkaloids: a review. Alkaloids 37:1-69.

Brown JH, Lynch DV, Thompson JE (1987) Molecular species specificity of phospholipids breakdown in microsomal 
membrane of senescing carnation flowers. Plant Physiol. 85:679-683.

Canel C, Lopes-Cardoso MI, Whitmer S, van der Fits L, Pasquali G, van der Heijden R, Hoge JH, Verpoorte R (1998) Effects of over-production of strictosidine synthase and tryptophan decarboxylase on alkaloid production by cell cultures of Catharanthus roseus. Planta 205:4-419.

Chia LS, Thompson JE, Dumbroff EB (1981) Simulation of the effect of leaf senescence on membrane by treatment with paraquat. Plant Physiol. 67:415-420.

Dalgarn DS, Newman DW (1986) Chapter 8. In: Purohit SS, (ed), Ecophysiology of Plant Membrane Lipids, Vol. 3, pp.66-85. Agro Botanical Publishers, Bekaner.

Droillard MJ, Bureau D, Paulin A (1989) Changes in activities of superoxide dismutase during aging of petals of cut carnations (Dianthus Caryophyllus). Physiol. Plant. 76:149-155.

Duxbury CL, Legge RL, Paliyath G, Barber RF, Thompson JE (1991) Alterations in membrane protein conformation in response to senescence-related changes. Phytochemistry 30:63-68.

Estevez JM, Cantero A, Reindl A, Reichler S, Leon P (2001) 1deoxy-D-xylulose-5-phosphate synthase, a limiting enzyme for plastidic isoprenoid biosynthesis in plants. J. Biol. Chem. 276:22901-22909.

Gardner HW (1968) Preparative isolation of monogalactosyl and digalactosyl diglycerides by thin-layer chromatography. Lipid Res. 9:139-141.

Hughes EH, Hong S-B, Shanks JV, San K-Y, Gibson SI (2002) Characterisation of an inducible promoter system in Catharanthus roseus hairy roots. Biotechnol. Prog. 18:1183-1186.

Hughes EH, Shanks JV (2002) Metabolic engineering of plants for alkaloid production. Metabol. Eng. 4:41-48.

Hughes EH, Hong S-B, Gibson SI, Shanks JV, San K-Y (2004) Metabolic engineering of the indole pathway in Catharanthus roseus hairy roots and increased accumulation of tryptamine and serpentine. Metabol. Eng. 6:268-276.

Jham GN, Teles FFF, Campus LG (1982) Use of aqueous hydrochloric acid/MeOH as esterification reagent for analysis of fatty acids. J. Am. Oil Chem. Soc. 59:132-133.

Koiwai A, Matsuzaki T, Suzuki F, Kawashima N (1981) Changes in total and polar lipids and their fatty acid composition in tobacco leaves during growth and senescence. Plant Cell Physiol. 22:1059-1065.

Lees G.L., Thompson J.E. (1980) Lipid composition in plasma membrane enriched fractions from senescing cotyledons. Physiol. Plant. 49:215-221.

Lichtenthaler HK (1999) The 1-deoxy-D-xylulose-phosphate pathways of isoprenoid biosynthesis in plants. Annu. Rev. Plant Physiol. Plant Mol. Biol. 50:47-65.

Lowry RR, Tinsley IJ (1976) Rapid colorometric determination of free fatty acids. J. Am. Oil Chem. Soc. 53:470-472.

Mahmoud SS, Croteau RB (2001) Metabolic engineering of essential oil yield and composition in mint by altering expression of deoxyxylulose phosphate reductoisomerase and menthofuran synthase. Proc. Natl. Acad. Sci. USA. 98:8915- 8920.

Matile PH, (1987) The sap of plant cells: a review. New Phytol. 105:1-26.

Mishra S, Sanwal GG (1994) Effect of Cuscuta infection on chloroplast lipid composition of Brassica leaves. Eur J. Plant Pathol. 100:61-70.

Mishra S, Sangwan RS (1996) Dynamics of tropane alkaloids in Duboisia myoporoides leaf during development. J. Herbs Spices Med. Plants 4:61-70.

Mishra S, Shanker S, Sangwan RS (1998) Lipid profile in relation to tropane alkaloid production and accumulation during leaf growth and senescence in Duboisia myoporoides. Fitoterapia 69:65-72.

Morgan JA, Shanks JV (2000) Determination of metabolic rate limitations by precursor feeding in Catharanthus roseus hairy root culture. J Biotechnol. 79:137-145.

Newman DW, Rowell BW, Byrd K (1973) Lipid transformations in greening and senescing leaf tissue. Plant Physiol. 51:229233.

Paliyath G, Droillard MJ (1992) The mechanisms of membrane deterioration and disassembly during senescence. Plant Physiol. Biochem. 30:789-812.

Rischer H, Oresic M, Seppänen-Laakso T, Katajamaa M, Lammertyn F, Ardiles-Diaz W, Van Montagu MCE, Inzé D, Oksman-Caldentey K-M, Goossens A (2006) Gene to metabolite networks for terpenoid indole alkaloid biosynthesis in Catharanthus roseus cells. Proc. Natl. Acad. Sci. USA 103:5614-5619.

Roughan PG, Batt RD (1968) Quantitative analysis of sulpholipids, sulphoquinovosyl diglycerides and galactolipids: Monogalactosyl diglycerides and digalactosyl diglycerides in plant tissues. Anal. Biochem. 22:74-78.

Rouser G, Kritchevsky G, Yamamoto A (1976) Column chromatographic and associated procedures for separation and determination of phospholipids and glycolipids. In: Marinetti GV (ed), Lipid Chromatographic Analysis, Vol. 3, pp.99-162, Marcel Dekker, New York.

Sangwan RS, Mishra S, Kumar S (1998) Direct fluorometry of phase-extracted tryptamine-based fast quantitative assay of L-tryptophan decarboxylase from Catharanthus roseus leaf. Anal. Biochem. 255:39-46.

Siakotes AN, Rouser G (1965) Analytical separation of nonlipid soluble substances and gangliosides from other lipids by dextran gel column chromatography. J. Am. Oil. Chem. Soc. 42:913-919.

Silvestrini A, Pasqua G, Botta B, Monacelli B, van der Heijden R, Verpoorte R (2002) Effect of alkaloid 
precursor feeding on a Camptotheca acuminate cell line. Plant Physiol. Biochem. 40:749-753.

Stadtman TC (1957) Preparation and assay of cholesterol and ergosterol. Meth. Enzymol. 3:392-394.

Suttle JC, Kende H (1978) Ethylene and senescence in petals of Tradescantia. Plant Physiol. 62:267-271

Suttle JC, Kende H (1980) Ethylene action and loss of membrane integrity during senescence Tradescantia. Plant Physiol. 65:1067-1072.

Thomas H, Stoddart JL (1980) Leaf senescence: a review. Annu. Rev. Plant Physiol. 31:83-111.

van der Fits L, Memelink J (2000) ORCA3, a jasmonateresponsive transcriptional regulator of plant primary and secondary metabolism. Science 289:295-297.

Verpoorte R, van der Heijden R, Van Gulik WM, Ten Hoopen
HJG (1991) Medicinal and pharmaceutical applications of indole alkaloids: a review. Alkaloids 40: 1-163.

Verpoorte R, van der Heijiden R, ten Hoopen HJG, Memelink J (1999) Metabolic engineering of plant secondary metabolite pathway for the production of fine chemicals. Biotechnol. Lett. 21:467-479.

Whitmer S, Canel C, Haijden R, Verpoorte R (2002a) Effect of precursor feeding on alkaloid accumulation by a strictosidine synthase over-expressing transgenic cell line SI of Catharanthus roseus. Plant Cell Tissue Organ Cult. 69:85-93.

Whitmer S, van der Heijden R, Verpoorte R (2002b) Effect of precursor feeding on alkaloid accumulation by a tryptophan decarboxylase over-production transgenic cell line T22 of Catharanthus roseus. J. Biotechnol. 96:193-203. 